\title{
The Influence Of Emotional Dissonance, Emotional Intelligence And Organizational Commitment On Job Satisfaction Of Employees Of Bank BUMN In Indonesia
}

\author{
Nyoman Gede Krishnabudi, Wiji Utami, Sudarsih \\ Dept. Management - Faculty of Economics and Business - University of Jember \\ Jember, East-Java, Indonesia \\ krishnabudi.feb@unej.ac.id
}

\begin{abstract}
This study aims to determine emotional dissonance, emotional intelligence as well as organizational commitment and their influences on job satisfaction of employees of Bank BUMN (state-owned banks) in Indonesia. The approach used in this research is a quantitative approach. The research population is 283 front office employees from 7 state-owned banks in Indonesia consisting of tellers, customer services staff, and marketing staff. All the 283 populations studied entirely. The methods of data analysis used multiple linear regression analysis. The results of test and analysis show that emotional dissonance has a negative and significant effect on job satisfaction of employees of Bank BUMN in Indonesia, emotional intelligence has a significant effect on employee job satisfaction and commitment have a positive and significant impact on job satisfaction of employees of Bank BUMN in Indonesia.
\end{abstract}

Keywords: emotional dissonance, emotional intelligence, organizational commitment, employee job satisfaction

\section{A. INTRODUCTION}

Working in the banking sector especially in the direct-related parts of the customer is a complex emotionally demanding job. In the context of organizational behavior, this is known as Emotional Labor (Karimi, Leggat, Donohue, Farrell \& Couper, 2014). Emotional Labor is defined as: "the effort, planning, and control necessary to express the emotion already planned during interacting with others" (Robbin \& Judge, 2015). Emotional Labor is one of the job requirements and should be disclosed and sometimes must be hidden (Diefendorff \& Gosserand, 2003). This research focused on bank employees that deal directly with customers. While interaction with customers, employees must be professional, displaying good emotions, showing quality as a reliable employee and showing commitment to the organization. 


\section{B. LITERATURE REVIEW}

\section{Emotional Dissonance}

Emotional dissonance is a core component of Emotional Labor (Zapf, 2002). Emotional Labor arises when employees express or suppress feelings that produce the right circumstances according to organizational rules (Hochschild, 1983). While expression in many cases arises spontaneously, in some situations this emotional suppression can lead to a conflict within a person although the person is well experienced. The gap between instantaneous emotion and the required emotion is called emotional dissonance (Brotheridge \& Grandey, 2002).

The researchers showed that employees perform emotionally related work using two acting techniques of deep acting and surface acting (Grandey, 2003). Employees develop surface acting when they change their outer appearance to simulate the emotions required. Surface acting produces the difference between perceived emotion and the emotion displayed. In-depth acting employees change not only their physical expressions but also their internal feelings. The effort to generate emotion that has been arranged and the emergence of emotions spontaneously will give effect to the job satisfaction of the employees of the Bank concerned. Thus, it can be stated the Hypothesis 1, that is, emotional dissonance affects job satisfaction of employee of Bank BUMN in Indonesia.

\section{Emotional intelligence}

Emotional Intelligence is divided into four categories of abilities, namely, the ability to perceive emotions, the ability to use emotions, the ability to understand, and the ability to manage emotions (Mayer \& Salovey, 1997). Previous research confirms that emotional intelligence affects job satisfaction, performance, work stress, absenteeism, and organizational commitment (Vigoda, 2010; Sy, Tram \& O'hara, 2006; Nikolaou \& Tsaousis, 2002).

Higher emotional intelligence has more mature emotions that allow them to cope with stress more wisely. Low emotional intelligence will have too much pressure because they lack self-awareness. Therefore, when they face tough conditions in their workplace, they can not control and overcome their feelings and may have negative job satisfaction and less organizational commitment (Sy, Tram, O'hara, 2006, Ami F. Utamia, Yuni R. Bangun, Donald C. Lantu, 2013). Emotional intelligence will affect a person to remain committed to the organization where he is. So, it can be stated the Hypothesis 2, that is, emotional intelligence influences on job satisfaction of employees of Bank BUMN in Indonesia.

\section{Commitment}

According to Robbins and Judge (2015:140), commitment to the organization is a situation where an employee sits with the organization and its goals, and intends to maintain membership within the organization. By having a high commitment to a 
company, an employee will improve the good performance of the company. Employees at BUMN Banks are committed to the companies in which they provide good services, deliver maximum performance to the company, are serious in their work, and keep themselves to work in the company.

The focus of organizational commitment has become a concern and is widely used both theoretically and empirically in Indonesia. The domains are organizational behavior, human resource management and industrial/organizational psychology (Mowday, Steers and Porter 1997). The concept of commitment has been used for decades. The concept of organizational commitment relates to employee intensity and dedication to an organization (Greenberg \& Baron, 2003). In harmony with this view, Rashid et al. (2003) suggest the characteristics of a committed employee who is energizing and showing loyalty to the organization through any situation, being present, working regularly, protecting organizational assets, and sharing in organizational goals. Organizational commitment is further described as the psychological attachment an employee has with an organization, strongly classified and willing to contribute to the achievement of organizational goals (Meyer and Allen, 1997). There are three components of organizational commitment that are widely used and adapted in research as described below.

a) Affective Commitment

Affective commitment is the emotional attachment and employee engagement of an organization. It involves two aspects, namely, the formation of emotional attachment to the organization and the desire to maintain organizational membership. The affective orientation of an organization occurs when the value of the employee is in line with the organization's interests. Therefore, the employee will be able to internalize the organization's value and objectives.

b) Continuance Commitment

Continuance Commitment refers to the appreciation of costs associated with leaving an organization (Meyer \& Allen, 1991), which is based on Becker's SideBet Theory (1960) and described as a component of the need or benefit versus losses working within an organization. The Side-Bet Theory specifies that when individuals remain in the work of an organization for a long time, they accumulate an investment that becomes costly when the individual leaves an organization.

c) Normative Commitment

Normative commitment is described as a feeling of obligation to continue membership in an organization. Employees with a sense of normative commitment feel compelled to stay within the organization. An employee who continues membership with an organization because of affective commitment shows a tendency to stay in an organization.

According to Robbins and Judge (2015: 140), commitment to the organization is a situation where an employee sits with the organization and its goals, and intends to maintain membership within the organization. By having a high commitment to a 
company, an employee will improve the good performance of the company. Employees at Bank BUMN are committed to the companies in which they provide good service, deliver maximum performance to the company, are serious in their work, and keep themselves to work in the company.

Affective commitment, continuance commitment, and normative commitment have a significant influence on job satisfaction of construction workers in South Africa (Manilall Dhurupa, Jhalukpreya Surujlala, Danny Mutamba Kabongo, 2016).

\section{Job Satisfaction}

High employee satisfaction is important to managers who believe that "an organization has a responsibility to provide employees with jobs that are challenging and intrinsically rewarding" (Robbins, 2009). Golbasi et al., (2008) defined job satisfaction as an emotional reaction and behavioral expression to a job that results from an individual assessment of his or her work achievement, office environment, and work life.

The concept of job satisfaction is a complex phenomenon that has been studied in various contexts. The most used definition of job satisfaction in organizational research is that of Locke (1976) who describes job satisfaction as a pleasurable or positive emotional state resulting from the assessment of one's job or job experiences which represents the feeling and the rationale about an individual's job. Since job satisfaction involves one's emotional feelings, it has major consequences on one's life. It can be viewed as a reaction to a job, arising from what an individual pursues in a job in comparison with the actual outcomes that the job provides to the individual (Rothmann and Coetzer, 2002). From this point of view, Sempane et al. (2002) consider job satisfaction as a result of an individual's perception and evaluation of a job, which is influenced by the individual's unique circumstances such as needs, values, and expectations. Building on this conceptualization, Spector (2003) and Robbins et al. (2009) assert that an employee who possesses positive attitudes or feelings towards a job may display higher levels of job satisfaction compared to an employee who holds negative attitudes or feelings towards a job. In the context of this study, job satisfaction is defined as the extent to which an employee is satisfied with the rewards received from a job (Statt, 2004). It is accepted as a complex concept that contains an employee's feelings about a variation of intrinsic and extrinsic job elements. Various elements come into play with regard to job satisfaction including the nature of the work, pay and promotion, supervision, co-workers relations.

From the explanation of the theory of commitment and previous research put forward the research hypothesis as follows:

Hypothesis 3: affective commitment has a significant effect on job satisfaction of employees of Bank BUMN in Indonesia. 
Hypothesis 4: continuance commitment has a significant effect on job satisfaction of employees of BUMN Bank in Indonesia.

Hypothesis 5: normative commitment has a significant effect on job satisfaction of employees of Bank BUMN in Indonesia.

\section{METHODOLOGY}

This type of research is quantitative research. Cross section data obtained from google form filled by respondents employees of Bank BUMN in Indonesia.

\section{Population}

The population consists of 83 employees of Bank BUMN in Indonesia which consists of tellers, customer service staff, and marketing staff, where these employees are the persons who interact directly with the customers. The categories of respondents are differentiated into sex, marital status, work experience and the department in which the respondent works. Measurement of emotional dissonance using the scale of the Frankfurt emotional (Zapf, Vogt, Seifert, Mertini, \& Isic, 1999) consisting of 5 items of answer choices ranging from never, ever, neutral, often to very often.

To assess the participant's emotional intelligence, the scale developed by Wong and Law (WLEIS - Wong \& Law Emotional Intelligence Scale) was used in this research. This emotional intelligence scale consisted of 16 items of questions with four dimensions such as an ability to feel self-emotion, others-emotion, and also the use of emotion and how they regulate their emotion. All the dimensions have 4 items questions each. The first dimension named Self-Emotion Appraisal (SEA) assess a person ability to understand their own emotions. The second dimension named OthersEmotion Appraisal (OEA) asses a person ability to understand other's emotion. The third dimension named Use of Emotion (UOE) is the person's ability to use their emotion to enhance their performance. The last dimension named Regulation of Emotion (ROE) which assess the person ability to manage their emotion.

Measurement of commitments using the commitment scale of Meyers and Allen (1997) and job satisfaction measurements using the scale from Brayfield and Rothe (1951) where respondents were given a choice of 5 choices of answers began strongly disagree, disagree, neutral, agree, and strongly agree.

2. Data Analysis

Data obtained in this study were analyzed using multiple linear regression analysis, while to test hypothesis 1 up to hypothesis 5 using $t$-test.

\section{RESULTS}




\section{Profile of Respondents}

The number of respondents were of 83 people consisting of 33 people $(39,8 \%)$ men and 50 people $(60,2 \%)$ women. The highest level of education is a bachelor of 66 people $(79.6 \%)$ and the 17 people $(20.4 \%)$ master degree. There were 17 people $(20.4 \%)$ respondents are married, 63 people (59\%) singles and 3 people (3.6\%) single parents. The experience consisted of 1-2 years working experience as many as 33 people (32\%), 2-4 years as many as 37 people (44\%) and more than 4 years as many as 13 people $(15,66 \%)$.

\section{Validity and Reliability}

The calculation showed that all items of the questionnaire are valid which correlation value is bigger than $r$-table, that is, 0.1937. For reliability test, all components are considered reliable because it has a Cronbach alpha value above 0.70 , emotional dissonance (Cronbach alpha) 0.980. Emotional intelligence (Cronbach alpha) 0.950. Affective commitment (Cronbach alpha) 0.992. Ongoing commitment (Cronbach alpha) 0.992. Normal Commitment (Cronbach alpha) 0.987.

\section{Regression Analysis}

Five independent variables (emotional dissonance, emotional intelligence, affective commitment, continuance commitment and normative commitment) and one dependent variable of job satisfaction were analyzed using multiple linear regression. Gray (2009) stated that regression analysis is used to understand how the independent variable affects the dependent variable and then do analysis on the relationship. Table 1 presents the results of multiple linear regression analysis of five independent variables on job satisfaction.

Table 1 Results of Regression Analysis

\begin{tabular}{|l|l|l|l|}
\hline \multicolumn{5}{|c|}{ Job satisfaction: dependent variable } \\
\hline Independent variable & Beta & $\mathrm{T}$ & Sig. \\
\hline Emotional Dissonance & -.188 & 2.322 & .034 \\
\hline Emotional Intelligence & .208 & 2.309 & .027 \\
\hline Affective Commitment & .253 & 2.576 & .011 \\
\hline Continuance Commitment & -.025 & 3.041 & .004 \\
\hline Normative Commitment & .250 & 2.960 & .022 \\
\hline $\mathrm{R}=0.445 \quad \mathrm{R}^{2}=0,198 \quad$ Adjusted $\mathrm{R}^{2}=0,626$ & \\
\hline
\end{tabular}

Source : Primer Data

Regression results indicate that the proportion of contribution of the independent variable to dependent variable is $62.6 \%$. The biggest contribution to job satisfaction is the affective commitment $(\beta=0.253)$. According to Giritli et al. (2013), normative commitment is related to an employee's feelings of responsibility to stay with the organizations due to the fact that the organizations have invested much in 
him/her. The positive relationship observed between normative commitment and job satisfaction suggests that an employee who is satisfied with pay and promotion, supervision, benefits, rewards, co-workers, nature of the work and communication seems to feel more indebted to remain with the organization. The normative commitment made the second highest contribution to job satisfaction $(\beta=0.250)$.

According to Spector (2003), job satisfaction relates to affective commitment and normative commitment, and this may be attributed to the notion that both job satisfaction and affective commitment relate to an employee's attachment and involvement with his/her respective organizations.

Meyer and Allen (1991) as well as Dhurupa, Surujlala and Kabongo (2016) found that job satisfaction relates positively to affective and normative commitment, and negatively associated with continuance commitment. The negative relationship between continuance commitment and job satisfaction suggests that employees' decision to continue membership within the organizations due to their emotional attachment (affective commitment) and obligation (normative commitment) may possibly be a result of their satisfaction with compensation and promotion, supervision, benefits, rewards, working conditions, co-workers, nature of work and communication, rather than the costs associated with leaving the organizations (Meyer \& Allen, 1997).

\section{Hypotheses Testing}

Hypothesis 1

From the result of calculation, it is known that $t$-value of emotional dissonance variable equals to 2.322 which is greater than $t$-table that is 1.632 , while significance equals to 0.034 which is less than 0.05 . Thus, the hypothesis is that emotional dissonance influences on job satisfaction of employees of Bank BUMN in Indonesia is accepted.

Hypothesis 2

From the calculation results, we note that $t$-value of emotional intelligence variable equal to 2.309 which is greater than $t$-table, that is, 1.632 with a value of significance is 0.027 that is less than 0.05 . Therefore, the hypothesis is that the emotional intelligence effects on job satisfaction of employees of Bank BUMN in Indonesia is accepted.

Hypothesis 3

The value of significance equals to 0.011 which is less than 0.05 , while the $t$ value of affective commitment variable equals to 2.576 which is greater than $t$ table that is 1.632 . Thus, the hypothesis is that affective commitment has a significant effect on job satisfaction is accepted.

Hypothesis 4

The value of significance equals to 0.004 which is less than 0.05 , while the $t$ value of continuance commitment variable equals to 3.041 which is greater than 
$t$-table that is 1.632 . Therefore, the hypothesis is that the continuance commitment has a significant effect on job satisfaction is accepted.

Hypothesis 5

The value of significance equals to 0.022 which is less than 0.05 , while the $t$ value of normative commitment variable equals to 2.960 which is greater than $t$ table that is 1.632 . Thus, the hypothesis is that the normative commitment has a significant effect on job satisfaction is accepted.

\section{E. DISCUSSION}

In carrying out duties as bank employees who interact directly with customers, the employees are required to serve the customer wholehearted to show good attitude and emotions. However, it is often happens the emotion condition that is not supposed to be, which will cause the employees have emotional dissonance. The results show that this emotional dissonance affects job satisfaction of the employees of Bank BUMN in Indonesia. This is because of the employees feel disappointed and show an attitude that should not be against the customers. Disappointment due to the emotional dissonance affects job satisfaction.

The emotional intelligence of state-owned bank employees demonstrates the ability to perceive emotions, the ability to use emotions, the ability to understand and the ability to manage emotions (Mayer \& Salovey, 1997). Based on the results of this research, all of these abilities were proved to affect employees' job satisfaction.

The affective and normative commitment were proved to affect job satisfaction of the employees of Bank BUMN in Indonesia. In line with the research conducted by Meyer and Allen (1991) as well as by Dhurupa, Surujlala, and Kabongo (2016), continuance commitment negatively affects job satisfaction.

\section{F. CONCLUSION}

There are many factors that affect employees' job satisfaction. Consistent with the previous research (Dhurupa, Surujlala, kobongo, 2016), this study found that organizational commitment was positively related to job satisfaction. Given the practical and theoretical importance of satisfaction, future research in this area is undoubtedly warranted. In line with other research ( Pohla, Santob, Battistelli, 2016), the ability to manage emotions is very important for employees who deal directly with customers.

\section{REFERENCES}

Allen, N. J., Meyer, J. P., (1996)., Affective, continuance and normative commitment to the organization: An examination of construct validity. Journal of Vocational Behaviour 49: 252-276. 
Ami F. Utami, Yuni R. Bangun , Donald C.Lantu (2014). Understanding the Role of Emotional Intelligence and Trust to the Relationship between Organizational Politics and Organizational Commitment, Procedia - Social and Behavioral Sciences (115) $378-386$

Brotheridge, C. M., \& Grandey, A. A. (2002). Emotional labor and burnout: Comparing two perspectives of "people work". Journal of vocational behavior, 60(1), 17-39. http://dx.doi.org/10.1006/jvbe.2001.1815

Diefendorff, J., Brown, D., Kamin, A., \& Lord, R. (2002). Examining the roles of job involvement and work centrality in predicting organizational citizenship behaviors and job performance. Journal of Organizational Behavior, 23, 93108. http://dx.doi.org/10.1002/job.123

Grandey, A. (2003). When "the show must go on": Surface acting and deep acting as determinants of emotional exhaustion and peer rated service delivery. Academy of Management Journal, 46, 86-96. http://dx.doi.org/10.2307/30040678

Greenberg, J., Baron, R. A., (2003). Behaviour in Organizations. 8thed. New Jersey: Prentice Hall.

Hochschild, A. R. (1983). The managed heart. Berkeley: University of California Press.

Kanter, Rosabeth Moss, (1968), Commitment and social organlzation. Astudy of commltment mechanisms in pian communities. American Sociological Review, 33' 499- 517

Karimi, L., Leggat, S. G., Donohue, L., Farrell, G., \& Couper, G. E. (2014). Emotional rescue: The role of emotional intelligence and emotional labour on well-being and job-stress among community nurses. Journal of advanced nursing, 70(1), 176-186. http://dx.doi.org/10.1111/jan.12185

Manilall Dhurupa, Jhalukpreya Surujlala, Danny Mutamba Kabongo. (2016). Finding Synergic Relationships in Teamwork, Organizational Commitment and Job Satisfaction: A Case Study of a Construction Organization in a Developing Country

Meyer, J. P., Stanley, D. J., Herscovitch, L., \& Topolnytsky, L. (2002). Affective, Continuance, and Normative Commitment to the Organization: A Meta-analysis of Antecedents, Correlates, and Consequences. Journal of Vocational Behavior, 61(1), 20-52. doi:10.1006/jvbe.2001.1842

Meyer allen.,(1991). a three component conceptualization of organizational commitment..Human resource management review, Vol 1. No.1, pg.61-89 
Meyer,J.P,Allen,N.,(1990). The measurements and antecedents of affective, continuance and normative commitment to the organization. Journal of Occupational Psycholo

Meyer, J.P., Allen, N.J., (1997). Commitment in the Workplace: Theory, Research, and Application. California: Sage Publications.

Mowday, R. T., Steers, R. M., and Porter, L. W., (1979)., The measurement of organizational commitment. Journal of Vocational Behaviour 14: 224-247.

Rashid, M.Z.A., Sambasivan, M., Johari, J., (2003). The influence of corporate culture and organizational commitment on performance. Journal of Management Development 22(8):708-728.

Robbin \& Judge, (2015). Organizational Behavior

Spector, P. E., (1997). Job satisfaction: Application, Assessment, Causes, and Consequences (Vol. 3). Sage.

Spector, P. E., (2006). Method Variance in Organizational Research: Truth or Urban Legend? Organizational Research Methods, 9, 221-232.

S. Pohla, L. Dal Santob, A. Battistelli (2016), Empathy and emotional dissonance: Impact on organizational citizenship behaviors

Zapf, D. (2002). Emotion work and psychological well-being. A review of the literature and some conceptual considerations. Human Resource Management Review, 12, 237-268. http://dx.doi.org/10.1016/S1053-4822(02)00048-7 